\title{
Treasury Single Account Policy and Revenue Generation Among Federal Parastatals in Ekiti-State, Nigeria
}

\author{
Oluyinka Ogungbade ${ }^{1}$, Omowumi Olanike Oshatimi ${ }^{2} \&$ Adebola Daniel Kolawole $^{1}$ \\ ${ }^{1}$ Department of Accounting, Afe Babalola University, Ado-Ekiti, Nigeria \\ ${ }^{2}$ Department of Accounting, Federal University, Oye-Ekiti, Nigeria \\ Correspondence: Oluyinka Ogungbade, Department of Accounting, Afe Babalola University, Ado-Ekiti, Nigeria.
}

Received: August 5, 2020

doi:10.5430/ijfr.v12n4p156
Accepted: September 14, 2020

Online Published: April 24, 2021

URL: https://doi.org/10.5430/ijfr.v12n4p156

\begin{abstract}
Treasury Single Account (TSA) is a new government policy to fight corruption in the Nigerian public sector. The policy has received a lot of compliments from many Nigerians; however, empirical studies have produced mixed results. The study examined the effects of Treasury Single Accounts (TSA) on the revenue generation of federal government parastatals in Ekiti state. The study specifically examined the effect of TSA on revenue generation of Federal University Oye-Ekiti, Federal Teaching Hospital Ido, Federal Road Safety Commission Ado-Ekiti and Federal Polytechnics Ado-Ekiti. Both Descriptive and inferential statistics were used. The descriptive statistics include mean, standard deviation, minimum and maximum while the study employed paired sample t-test for inferential analysis. The study reveals that TSA has not enhanced the revenue generation among federal government parastatals in Ekiti state. The research further shows that TSA is counterproductive since average revenue generated after the implementation of TSA is lower than the average revenue that the parastatals generated before the implementation of TSA. The study recommends that the federal government of Nigeria should investigate the reasons why the TSA is counterproductive in Ekiti state and adequately monitor its implementation.
\end{abstract}

Keywords: treasury single accounts, revenue, parastatals

\section{Introduction}

Nigeria is blessed with numerous human and natural resources so much that it is being regarded as the giant of Africa. However, it is one of the poorest and less-developed nations in the world today as a result of corruption (Eme, Chukwurah, \& Emmanuel, 2015). The directive from the federal Government that all government revenues must be paid into the Treasury Single Account (TSA), was in a bid to curtail the prevalent corruption in the country (Eme et al., 2015). All governments revenues are normally paid into the consolidated revenue fund, but this did not capture idle funds which created room for corruption and forced government to borrow money to finance its budget deficits when its huge amount of money are idle in various banks(Ajala, Adesanya, \& Oyewale, 2017). Researchers have prescribed TSA as a requirement for public financial management for its effectiveness in oversight control of government's cash resources, improving quality of financial information, reducing debt servicing cost, and increasing return of investment of surplus cash (Pattanayak \& Fainboim Yaker, 2011). Also, scholars have advocated for the sustainability of TSA having perceived it as a good mechanism for fighting corruption in Nigeria (Ganyam, 2020). The directive has however generated mixed feelings as it is seen by some as a very good policy adopted by the President Muhammadu Buhari led administration in the fight against corruption while others disagree. Even though TSA has been implemented in developed countries including USA, UK, France, Sweden, India and Indonesia for many decades without generating any tension, it is relatively new in Nigeria, and its implementation generated perceived tensions (Muraina, 2018).

Treasury Single Account (TSA) is a government accounting system which ensures all public revenue, earnings and proceeds are collected into one single account (Ejoh, 2020). This account is often maintained by the nation's Central Bank. The supporters of Treasury Single Account argue that it will help to guarantee proper cash management by ensuring greater transparency and accountability in Public finance, blocking leakages in revenue and eradicating misappropriation of public funds (Adetula, Adegbenjo, Owolabi, Achugamonu, \& Ojeka, 2017; Igbekoyi \& Agbaje, 2017). 
Treasury Single Account was introduced to monitor government revenue as well as block all loopholes leading to corruption in Nigeria. The implementation of TSA which came into effect from April, 2015 has gone a long way in correcting government fund mismanagement. The directive which the federal government of Nigeria gave that all Ministries Departments and Agencies (MDAs) to implement TSA has received wide commendation as a bold step to stem corruption in the country. With all revenues going into a Single Treasury Account, government will have an overview of the money it has in its account so as to better plan its expenditure. Due to this, the leakages that used to be there in the system where people used money as they want and decided what to return to the government will no longer happen. Mahmud (2019) reported that after the implementation of TSA, one of the federal government parastatals in Nigeria, Joint Admission and Matriculation Board (JAMB), remitted 7.8 billion naira to government coffer in 2017 alone after deducting all expenses. In contrast, before the implementation of TSA, the same body remitted about 52 million naira in entire 40 years of its existence.

Prior to the implementation of the TSA policy, previous studies have shown that several government agencies were evidently involved in the fraudulent diversion of government funds through unapproved bank accounts. Consequently, the misappropriation of funds by ministries and extra ministerial departments of government has caused great financial loss to the federal government to the tune of trillions of naira (Bashir, 2016; Ndubuaku, Ohaegbu, \& Nina, 2017). Mismanagement of public funds was also resulted from poor record keeping of revenue generated from inception stage to the stage of final remission to government coffer. Previous studies have generated mixed results (Igbekoyi \& Agbaje, 2017; Ofor, Omaliko, \& Okoli, 2017; Ofurum, Oyibo \& Ahuche, 2018) while conclusions drawn from some other studies conducted on Treasury Single Account Adoption and its effect on revenue generation were based on people's opinion and not on the government revenue data made available by Central Bank of Nigeria hence, this study. This study therefore seeks to examine the effect of TSA on Revenue Generation of Federal Parastatals in Nigeria.

\section{Literature Review}

\subsection{Treasury Single Account, Revenue Generation and Federal Parastatals}

Treasury Single Account (TSA) is financial policy in operation in many nations of the world. The federal government of Nigeria implemented the policy in 2015 to consolidate all revenues from all agencies of government into a single account domiciled at the Central Bank of Nigeria (CBN). TSA was introduced so as to monitor the government revenue and also suppress the corruption in Nigeria. TSA is relatively new public accounting system; it uses a single account for a set of linked account by the government (Lienert, 2009). Even though, TSA is relatively new in Nigeria, it has been in operation in US, UK, France and some other developed nations, and some emerging economies including India and Indonesia for many years(Eseoghene, Estemetan, \& Oghenevwogaga, 2018).

Section 162 (10) of Nigeria 1999 Constitution defines Revenue as" any income or return accruing to or derived by the Government of the Federation from any source. It therefore, includes any receipt, however described, arising from the operation of any law, any return, however described arising from or in respect of any property held by the Government of the Federation or any return by way of interest on loans and dividend in respect of shares or interest held by the Government of the Federation in any Company or Statutory body" (Constitution, 2004 p.103).

This means establishments that are owned wholly or partly by the government. They manage government revenue with primary consideration of the citizens, stakeholders of government revenue, in turn, demonstrates their positive approaches and behaviours towards their civic duties, making the use of the stakeholders' energy to execute the government's aims

\subsection{Empirical Review}

Muraina (2018) employed correlational research design and Feasible Generalized Least Square to determine the effect of TSA on banks and liquidity in Nigeria. The study's outcome revealed that federal government deposit significantly increased the bank liquidity before the implementation of TSA, but significantly decreased the banks' liquidity performance after the implementation of TSA. Also, in a study conducted on the origin, nature, and challenges of TSA in Nigeria, TSA was recommended for Nigeria to drive its economic growth and development; the authors concluded that TSA is not infallible and that the regulatory authorities should address its lapses(Ikya, Akaa, \& Ucherwuhe, 2017).

In like manner, Amadi and Obutte (2018) argued that TSA ensures compliance with the Nigerian 1999 constitution. Still, to ensure its legality, the Government must develop a robust legal and institutional reform. The Government should also ensure its sustainability by demonstrating the political will to deal with any revenue collection agency that may want to circumvent it. Similarly, using secondary data and content analysis techniques, Ahmed-Gamgum 
and Ahmed (2018) argued that TSA is an international best practice in monetary and fiscal policy-making for economic development. It came due to the push to save more funds through a mixture of fiscal and monetary policy for rural and urban development

In Ondo State, Nigeria, TSA's effect on the accountability and transparency of the Public Sector was examined. The analysis of the data collected from 100 respondents from purposively selected MDAs out of the total 150 MDAs in the state reveals that TSA effectively blocks financial leakages in the public sector (Lodikero, Fagbayimu, \& Olateru-Olagbegi, 2018). However, Mboto, Offiong and Ibor(2017) investigated Nigerians' perception towards the TSA using a sample of one hundred and ninety respondents, drawn from MDAs and Deposit Money Banks in Calabar Cross River State. The authors concluded that TSA hurts the people's social-economic life and the operations of MDA due to administrative hitches.

The analysis of the data collected via questionnaire from 389 respondents comprising the staff of the Accountant General's office, Auditor General's office, Central Bank of Nigeria, and federal ministry of finance revealed that TSA has a considerable negative effect on the cost of revenue generation. The study shows that TSA charges' entire burden is placed on the citizens (Agbo, Suleiman, \& Okwoli, 2019).

In Turkey, the TSA scope has been widened and backed up with a presidential decree dated August 8, 2018; the effect of the extended scope on Turkish financial management has been investigated. The results show that comprehensive TSA has a positive effect on Turkish public finance in terms of the increased colossal amount of public resources to be managed by the Turkish treasury and significant additional revenue from its deposit (Can, 2019).

Treasury Single Account has also been described as a tool for fighting financial leakages and corruption by enhancing accountability and transparency; however, it has led to job loss in the banking sector and lower profit and companies' income tax (Oti, Igbeng, \& Ndifon, 2016). Ajibade, Oyedokun and Doumu (2018) advocated for the continuity of TSA, having found out through a survey design that TSA improves accountability and transparency and reduces leakages in the financial system.

Also, Badejo, Oluwaseyi and Taiwo (2017) established that TSA is a required precondition for modern cash management and is a useful tool for monitoring Government's receipts and expenditures. However, to effectively fight corruption in Nigeria, some funds such as grants that Nigerian universities receive from international and corporate bodies should be exempted from the TSA (Esoimeme, 2019).

Similarly, a descriptive and paired sample t-test of the TSA and liquidity of 15 listed banks in Nigeria revealed that TSA hurt the liquidity base of banks in Nigeria and a considerable impact on their profit after tax (Ajetunmobi, Adesina, Faboyede, \& Adejana, 2017). A similar study also argued that the announcement and subsequent implementation of TSA negatively impacted shareholders 'wealth in commercial banks in Nigeria(Moses, Ehalaiye, Maimako, \& Fasua, 2018). However, for financial institutions that sincerely seek financial gain, it has been argued that TSA has opened windows of opportunity for unexplored and uncontested huge goldmine which offers an inexpensive and steady source of funds for lucrative growth (Ikya, 2019)

Correlation analysis of data collected from 100 M.sc class of Business Education, River State University, Nigeria, on business environment characteristics and new venture creation revealed that TSA promotes trust and strengthens business practices and transparency (Ikpesu, 2018). Likewise, existing studies reveal that TSA reduces financial leakages, pilfering, embezzlement, fraud, and forgery, but its effect on bribery and contract inflation is not statistically significant (Habeeb, 2020).

The analysis of data collected from 75 respondents from federal parastatals in Anambra metropolis in Nigeria showed that TSA is capable of blocking financial leakages in revenue generation and promoting transparency and accountability (Ofor et al., 2017). Similarly, Igbekoyi and Agbaje (2017) established from the analysis of primary data collected from 10 purposively selected parastatals that TSA considerably has positive impact on financial leakages, transparency and financial misappropriation.

However, Ofurum, Oyibo and Ahuche (2018) assert that the implementation of TSA has not enhanced revenue generation in Nigeria, but it has positively enhanced the economic growth. This assertion was made having analyzed the revenue generated by the federal government from 2013-2017 using a paired sample t-test analytical technique for a pre-test post-test design.

In like manner, Ndubuaku et al. (2017) conducted a research on Impact of Treasury Single Account on the Performance of the Banking Sector in Ebonyi State, Nigeria. The analysis of secondary data collected from 24 banks 
via regression and correlation analysis showed that TSA considerably reduced credits to private sector, deposit mobilization and loans and advances.

Also, Nwankwo (2017) carried out a study on the challenges and prospect of transition to Treasury Single Account (TSA). The analysis of the primary data collected from 30 respondents from Enugu state University of technology shows that TSA implementation in Nigeria is beneficial. The extant literature shows that TSA, together with Integrated Payroll and Personnel Information System (IPPIS), and Integrated Financial Management Information System (IFMIS) reduce corruption in the Nigerian public sector (Abodunrin \& Omole, 2017).

Similarly, Haruna, Alabade and Umar (2017) stated that the adoption of TSA in Nigeria is commendable and timely given the current economic challenges due to dwindling oil revenue and constrained public spending. Moreover, the authors assert that TSA has the potential to eradicate leakages and corruption and ensure accountability and transparency.

In like manner, Udo and Esara (2016) studied the cost and benefits of TSA and its prospects for state government in Nigeria. The study administered survey questionnaires to 200 professionals Accountants in Akwa Ibom State so as to elicit information on the benefits of the adoption and full implementation of TSA by the state governments of Nigeria. The result of the primary data reveals that the research participants perceive TSA as tool for avoiding misappropriation of revenue and ensuring accountability and transparency. The study conducted by Bashir (2016) used primary data to measure the effect of TSA on Public Finance Management in Nigeria.

Oguntodu, Alalade, Adekunle and Adegbie (2016) also investigated the Treasury Single Account and Nigeria's Economy Between 1999 and 2015. The study affirmed that about $99.12 \%$ of total variations in the Nigerian Economy are explained by the TSA indicators.

Based on the empirical review, it can be noted that some studies formed their conclusions based on people's opinion and not on the government revenue data made available by Central Bank of Nigeria (Udo \& Esara,2016; Bashir,2016). Other studies focused on how TSA affect the commercial banking sectors (Kanu, 2016; Ndubuaku et al., 2017). Besides, the existing studies have produced mixed results (Igbekoyi \& Agbaje, 2017; Ofor et al., 2017; Ofurum et al., 2018). In addition, the existing studies did not analyze each parastatal individually which this study did to identify the effect of the policy on each of the parastatals examined. As a result, this study examined the impact of TSA on revenue generation by comparing the total revenue generated before and after the implementation of TSA. Thus, the following hypotheses were tested:

$\mathrm{H}_{0}$ 1: There is no significant difference between the revenue generated by the Federal University Oye-Ekiti before the implementation of TSA and the revenue that the University generated after the implementation of TSA.

$\mathrm{H}_{0}$ 2: There is no significant difference between the revenue generated by the Federal Teaching Hospital Ido -Ekiti before the implementation of TSA and the revenue that the parastatal generated after the implementation of TSA.

$\mathrm{H}_{0} 3$ : There is no significant difference between the revenue generated by the Federal Road Safety Commission Ado-Ekiti before the implementation of TSA and the revenue that the commission generated after the implementation of TSA.

$\mathrm{H}_{0} 4$ : There is no significant difference between the revenue generated by the Federal Polytechnic Ado-Ekiti before the implementation of TSA and the revenue that the institution generated after the implementation of TSA.

$\mathrm{H}_{0} 5$ : There is no significant difference between the revenue generated by the Federal Government Parastatals in Ekiti state, Nigeria before the implementation of TSA and the revenue that the parastatals generated after the implementation of TSA.

\section{Methods}

Since the study intends to find out the effect of TSA on Revenue generation, the explanatory research design was adopted using the secondary data that were extracted from CBN statistical bulletin and the Financial Statements of selected Federal Parastatals covering a period of 2013 - 2018. The study employed both descriptive and inferential statistics for a detailed analysis of the variables. Descriptive analysis was used to assess the trend of government revenue generated before and after treasury single account while inferential statistics was used to examine the difference in revenue generation of each selected federal parastatal before and after the implementation of TSA.

Paired sample t-tests were carried out on each of the hypotheses, by making the first three years of revenue generation the period before the implementation of TSA, while the last three years were the years of implementation of TSA by the parastatals. Since, they were the actual years of implementation after they were adopted in 2015; the 
implementation of TSA in parastatals began in the year 2016. There are two periods involved in the analysis. These periods were pre and after the commencement of Treasury Single Account. The study covered a period of six years, which were broken into two parts. The two parts were: the three years that preceded implementation of TSA, which was 2013 to 2015 and the three years immediately after the implementation of TSA commenced, which were 2016 to 2018.

Table 1. Sample of selected federal parastals in Nigeria

\begin{tabular}{l}
\hline Selected Federal Parastatals \\
\hline Federal University Ado-Ekiti \\
Federal Teaching Hospital Ido-Ekiti \\
Federal Road Safety Commission \\
Federal Polytechnic Ado-Ekiti \\
\hline
\end{tabular}

According to Table 1 above, the population of the study consisted of 12 federal parastatals from Ekiti state, Nigeria. These are federal government established revenue generating agencies as at 2018 (FRC, 2018). They cut across different ministries such as; education, health, finance, transportation, works and housing among others. Samples of 4 selected federal parastatals were drawn from the population. This was achieved after using 2-stage filtering criteria. The first criterion was that the agency must have being in existence prior to 2008 and should have been established via an act or decree. The second criterion was that they must have been remitting to the government coffers on a yearly basis.

\subsection{Description of the Samples}

\subsubsection{Federal Teaching Hospital Ido-Ekiti}

The Federal Teaching Hospital was established as Federal Medical Center in 1998 by the administrative pronouncement of the then military Head of State and as part of the Federal Government policy to establish Federal Medical Centre in the States where there was no Teaching Hospital. It was an offshoot of the then Ido General hospital, which was established in 1956. The hospital started administration operation in July 1998 but commenced full operations in 1999. The hospital was upgraded by the Federal Government into a Teaching Hospital in partnership with Afe Babalola University, Ado Ekiti (ABUAD) in October, 2014.

\subsubsection{Federal Polytechnic Ado-Ekiti}

The Federal Polytechnic Ado-Ekiti was established in January 1977 in Jos, Plateau State. In 1978, it was moved by the Federal Government of Nigeria to Akure, Ondo State in order to maintain an equitable spread of Federal Government institutions among the states of the Federation. In accordance with Decree 33 of 1979, its status was changed from that of a College of Technology to a full-fledged Polytechnic. In 1982, the Institution was once again relocated by the Federal Government to Ado-Ekiti, now the capital of Ekiti State. The relocation was done to pave way for the establishment of Federal University of Technology at its site in Akure. By 1986, the movement of the institution to its permanent site was completed.

\subsubsection{Federal University Oye-Ekiti}

Federal University Oye, Ekiti, was established in Oye- Ekiti in 2011 as one of the nine Federal Universities established by the Federal Government of Nigeria, pursuant to an executive order made by the President of the Federal Republic of Nigeria, His Excellency, Dr. Goodluck Ebele Jonathan, GCFR. Federal University Oye-Ekiti, whose pioneer Vice Chancellor, is Professor Chinedu Ostadinma Nebo, OON, has two campuses at Oye-Ekiti and Ikole-Ekiti with 4 Faculties and 27 Departments.

\subsubsection{Federal Road Safety Commission Ado-Ekiti}

This is a Government Agency with statutory responsibilities for road safety administration in Nigeria. Founded in 1988, the Federal Road Safety Corps (FRSC) operates in all Nigerian states as well as the Federal Capital Territory and is the lead agency in Nigeria on road safety administration and management. The statutory functions include: Making the highways safe for motorists and other road users as well as checking road worthiness of vehicles, recommending works and infrastructures to eliminate or minimize accidents on the highways and educating motorists and members of the public on the importance of road discipline on the highways. 


\subsection{Model Specification}

Existing theories did not provide sufficient models for determining treasury single account and revenue generation of federal parastatals in Nigeria. Due to this, models were developed for this study to examine the difference in revenue generation of Federal Teaching Hospital Ido-Ekiti, Federal Polytechnic Ado-Ekiti, Federal Road Safety Commission in Ekiti and Federal University Oye-Ekiti before and after the implementation of TSA.

The Paired Sample T-Test was used to analyze data, in order to achieve the objectives above. The paired sample t-test is a statistical procedure used to determine whether the mean difference between two sets of observations is zero(Field, 2009). In a paired sample t-test, each entity is measured twice, resulting in pairs of observations. The paired sample t-test was used to find out whether the implementation of TSA affects revenue generation of Federal Government Parastatals or not.

Due to this, the study employed the following model:

$$
\mathrm{t}=\underline{\overline{\mathrm{x}}}_{\text {diff }^{-}} 0
$$

Where: $\mathrm{S} \overline{\mathrm{x}}=\underline{\mathrm{S}}_{\text {diff }}$

$$
\sqrt{n}
$$

$\overline{\mathrm{x}}_{\text {diff }}=$ Sample mean of the difference

$\mathrm{n}=$ Sample size (i.e number of observation)

$\underline{S}_{\text {diff }}=$ Sample standard deviation of the difference

$\mathrm{S}_{\overline{\mathrm{x}}}=$ Estimated standard error of the mean

\subsection{Description and Measurement of Variables}

The variables were the revenue generation of the parastatals for the period of six years that were broken into two parts, based on the implementation of TSA, which occurred in 2016, even though the adoption of TSA was in the year 2015, the actual implementation of it took place in all the sampled parastatals in the year 2016. Each of the periods were three years, meaning three in two places, making six years in all for each of the study period.

\section{Results and Discussion}

This section presents the results of the analysis of data used to achieve the objectives of the study. The results are presented in tables with corresponding interpretations and discussion

\subsection{Descriptive Analysis}

The descriptive analysis is summarized in Table 2 below:

Table 2. Descriptive statistics

\begin{tabular}{llllll}
\hline & $\mathrm{N}$ & Minimum & Maximum & Mean & Std. Deviation \\
\hline FUOYE POSTTSA & 3 & 224451107.66 & 643597865.40 & 426774456.8533 & 209949255.58793 \\
\hline FUOYE PRE TSA & 3 & 16070560.00 & 156405659.63 & 88173546.3100 & 70247582.09589 \\
\hline FMC IDO PRE TSA & 3 & 100979465.20 & 259581326.00 & 204740527.0667 & 89908462.65177 \\
\hline FMC IDO POST TSA & 3 & 122615905.00 & 217850681.00 & 163961253.6667 & 48840875.01406 \\
\hline FRSC ADO PRE TSA & 3 & 36636000.00 & 58710000.00 & 50941333.3333 & 12404087.12213 \\
\hline FRSC ADO POST TSA 3 & 32676000.00 & 56244000.00 & 45311333.3333 & 11875898.33795 \\
\hline FEDPOLY PRE TSA & 3 & 581705946.00 & 758337787.00 & 682536005.6667 & 90936861.89335 \\
\hline FEDPOLY POST TSA & 3 & 446676790.00 & 661370000.00 & 587456533.0000 & 121969741.14348 \\
\hline TOTAL PRE TSA & 3 & 969967691.30 & 1074432912.00 & 1026391412.4333 & 52734635.79821 \\
\hline TOTAL POST TSA & 3 & 826419802.70 & 1579062546.00 & 1223503576.9000 & 378035721.64477 \\
\hline Valid N (listwise) & 3 & & & &
\end{tabular}

Source: Author's computation (2020) 
According to Table 2, the minimum revenue generated by the Federal University Oye-Ekiti (FUOYE) was $\$ 16,070,560.00$, while the maximum amount was $\$ 156,405,659.63$ and the average revenue generated was $\$ 88,173,546.3100$ with the standard deviation of $\$ 70,247,582.09589$. However, after the implementation of TSA, the minimum revenue generated by the institution was $\$ 224,451,107.66$ while the maximum amount was $\$ 643,597,865$.40. On average, the revenue generated by the institution before the adoption of TSA was $\$ 426,774,456.8533$ which is higher than the average revenue that the institution generated before TSA by $\$ 338,600,910,5433$ ( $\$ 426,774,456.8533-\$ 88,173,546.3100$ ). The revenue generated during the period spread from the average by $209,949,255.58793$.

However, Federal Teaching Hospital (FTH) Ido, generated a minimum revenue of $\$ 100,979,465.20$ and a maximum revenue of $\$ 259,581,326.00$ before the adoption of TSA. On average, the parastatal generated a sum of \$204740527.1 with a spread of $\$ 89908462.65$ during the period. After the implementation of TSA, the parastatal however recorded a minimum revenue of $\$ 122,615,905.00$ and a maximum revenue of $\$ 217,850,681.00$ which is even lower than the maximum recorded before the adoption of TSA. On average, the parastatals recorded a sum of \$163,961,253.67 after the implementation of TSA which is lower than average amount recorded before the implementation of TSA. The spread of the revenue from the mean during the period was $448,840,875.01$.

In like manner, the Federal Road Safety Commission (FRSC) Ado-Ekiti recorded a minimum amount of $\$ 36,636,000.00$ and a maximum amount of $\$ 58710000.00$ before the implementation of TSA. The average revenue recorded by the agency during the period was $\$ 50,941,333.33$ with the spread of $\$ 12404087.12$ around the mean. In contrast, after the implementation of TSA, the agency recorded a minimum sum of $\$ 32,676,000.00$ which is lower than the minimum recorded before TSA, and a maximum amount of $\$ 56,244,000.00$ which is equally lower than the maximum recorded before TSA. On average, the parastatal generated a sum of $\$ 45,311,333.33$ which is also lower than the average recorded before the implementation of TSA. The revenue generated during the period spread around the mean by 11875898.33 .

In the same way, Federal Polytechnics Ado -Ekiti, generated a minimum amount of $\$ 581,705,946.00$ and a maximum amount of $\$ 758,337,787.00$ before the implementation of TSA. On average, the institution generated a sum of $\$ 682,536,005.67$ during the period and the standard deviation of the revenues from the average was $\$ 90,936,861.89$. In contrast, the institution generated a minimum amount of $\$ 446,676,790.00$ after the implementation of TSA and a maximum amount of $\$ 661,370,000.00$ which are lower than the amount recorded before the implementation of TSA. On average, the institution generated a sum of $\$ 587,456,533.00$ which is lower than the amount recorded before the implementation of TSA. The spread of revenue generated around the average during the period was $\$ 121969741.14$ which was greater than the spread before TSA.

Finally, the overall minimum amount that the parastatals generated before the adoption of TSA was $\$ 969,967,691.30$ and the overall maximum amount the parastatals generated during the period was $\$ 1,074,432,912.00$. On average, the revenue generated by the selected parastatals during the period was $\$ 1,026,391,412.43$ and the spread of revenue generated around the mean was $\$ 52,734,635.80$. However, the minimum amount that the parastatals generated after the implementation of TSA was $\$ 826,419,802.70$ which is even lower than the minimum generated before the implementation of TSA. Likewise, the maximum amount the parastatals generated during the period was $\$ 1,579,062,546.00$ which was more than the maximum amount they recorded before the implementation of TSA. On average, the amount that the selected parastatals generated after the implementation of TSA was $1,223,503,576.90$ which was slightly higher than the average revenue that they generated before the adoption of TSA. The spread of revenue that the parastatals generated after the implementation of TSA from the mean was $\$ 378,035,721.65$ which was considerably higher than the spread before the adoption of TSA.

\subsection{Normality Test}

The study employed Shapiro-Wilk to test the normality of the variable before proceeding to inferential tests.

Table 3. Test of normality

\begin{tabular}{llll}
\hline Shapiro Wiki Test & Statistics & Df & Sig \\
\hline FUOYE PRE TSA & .998 & 3 & .909 \\
\hline FUOYE POST-TSA & .996 & 3 & .886 \\
\hline FMC IDO PRE TSA & .778 & 3 & .063 \\
\hline
\end{tabular}




\begin{tabular}{llll}
\hline FMC IDO POSTTSA & .951 & 3 & .572 \\
\hline FRSC ADO PRE TSA & .792 & 3 & .095 \\
\hline FRSC ADO POST TSA & .985 & 3 & .762 \\
\hline FEDPOLY ADO PRE TSA & .943 & 3 & .540 \\
\hline FED POLY ADO POST TSA & .775 & 3 & .055 \\
\hline TOTAL PRE TSA & .981 & 3 & .736 \\
\hline TOTAL POST TSA & .991 & 3 & .818 \\
\hline
\end{tabular}

Source: Authors Computation (2020)

According to Table 3, the P-values of all the variables are higher than 0.05 which implies that the deviation from normality is not significant. These results reveal that all the variables are normally distributed.

\subsection{Inferential Analysis}

The study used paired sample t-test to test the four hypotheses of the study and drew inferences from the outcomes

\subsubsection{Paired Sample Correlation}

The outcome of the paired sample correlation is presented in Table 4.

Table 4. Paired sample correlation

Paired Samples Correlations

\begin{tabular}{lllll}
\hline & & $\mathrm{N}$ & Correlation & Sig. \\
\hline Pair 1 & FUOYE PRETSA \& FUOYE POST TSA & 3 & .510 & .659 \\
\hline Pair 2 & FTH IDO PRE TSA \&FTH IDO POST TSA & 3 & -.965 & .170 \\
\hline Pair 3 & FRSC ADO PRE TSA \& FRSC ADO POST TSA & 3 & .940 & .222 \\
\hline Pair 4 & FEDPOLY ADO PRE-TSA \& FEDPOLY ADO POSTTSA & 3 & .968 & .162 \\
\hline Pair 5 & TOTAL PRE -TSATSA \&TOTAL POST TSA & 3 & .999 & .027
\end{tabular}

Source: Authors Computation (2020)

Table 4 shows that there is an insignificant positive and moderate relationship between the revenue generated by Federal University Oye-Ekiti (FUOYE) before the adoption of TSA and the revenue generated by the institution after the implementation of TSA $(r=.510, p>.05)$. This finding shows that the amount of income that the institution was remitting to government treasury before it implemented TSA is abstemiously similar to amount it has been remitting to the government coffer after the implementation of TSA. The association is however not statistically important.

Similarly, there was an insignificant adverse and strong relationship between the revenue that Federal Teaching Hospital (FTH) Ido- Ekiti was remitting to the government before the implementation of TSA and the revenue the parastatal has been remitting to government after the implementation of TSA $(r=-, 965, p>.05)$. In the same manner, the study reveals an insignificant positive and strong relationship between the revenue that Federal Road Safety Commission (FRSC) Ado-Ekiti was remitting before the adoption of TSA and the revenue it was remitting after the implementation of TSA $(r=.940, p>0.05)$.

The finding further reveals that the relationship between the revenue that Federal Polytechnics (FEDPOLY) Ado was generating before the adoption of TSA and the revenue that the institution was generating after the adoption of TSA are insignificantly positive and strong $(r=.968, \mathrm{p}>.05)$. The implication of this finding is that the rate of increase in revenue generation before the adoption of TSA and the rate of revenue generation after the adoption of TSA almost the same. However, it is not statistically significant at $5 \%$ level of significance.

In like manner, the outcome of this study shows that there was a significant positive and strong correlation between the revenue that Federal government parastatals in Ekiti state were generating before the adoption of TSA and the revenue they were generating after the implementation of TSA $(r=.999, \mathrm{p}<.05)$. This result implies that statistically the level of increase in revenue generation by the federal government parastatals in Ekiti state before the adoption of TSA is almost the same with what they have been remitting even after the implementation of TSA. 


\subsubsection{Tests of Hypotheses}

The hypotheses of the study are tested based on the results presented in Table 5.

Table 5. Paired sample test

\begin{tabular}{|c|c|c|c|c|c|c|}
\hline \multirow[t]{2}{*}{ Pairs } & \multirow[t]{2}{*}{ Mean } & \multicolumn{2}{|c|}{ 95\% Confidence intervalofthedifference } & \multirow[t]{2}{*}{$\mathbf{t}$} & \multirow[t]{2}{*}{ df } & \multirow[t]{2}{*}{ Sig } \\
\hline & & Lower & Upper & & & \\
\hline Pair1 & 338600910.54 & 119160115.99 & 796361937.09 & 3.183 & 2 & .086 \\
\hline \multicolumn{7}{|l|}{$\begin{array}{l}\text { FUOYE PRE TSA* } \\
\text { POST TSA }\end{array}$} \\
\hline Pair 2 & 40779273.40 & -301109365.51 & 382667912.31 & & 2 & .659 \\
\hline $\begin{array}{l}\text { FMC PRE \& POST } \\
\text { TSA }\end{array}$ & & & & .513 & & \\
\hline $\begin{array}{l}\text { FRSC PRE \&POST } \\
\text { TSA }\end{array}$ & 5630000.00 & -4933772.18 & 16193772.18 & 2.293 & 2 & .149 \\
\hline $\begin{array}{l}\text { FEDPOLY } \\
\text { PRR-POST TSA }\end{array}$ & 95079472.67 & -6587652.73 & 196746598.06 & 4.024 & 2 & .057 \\
\hline $\begin{array}{l}\text { TOTAL PRE TSA } \\
\& \text { TOTAL POST } \\
\text { TSA }\end{array}$ & -197112164.47 & -1005344410.31 & 611120081.38 & -1.049 & 2 & .404 \\
\hline
\end{tabular}

Source: Authors Computation (2020)

There was no significant average difference between the revenue generated by Federal University Oye-Ekiti (FOUYE) before the adoption of TSA and after the adoption of TSA $\left(t_{2}=3.183, p>.05\right)$. Therefore, the first hypothesis of this study which state that "There is no significant difference between the revenue generated by the Federal University Oye- Ekiti before the implementation of TSA and the revenue that the institution generated after the implementation of TSA" is accepted. On average, revenue generated by FUOYE after the adoption of TSA is three hundred and thirty-eight million, six hundred thousand and nine hundred and ten-naira fifty-four kobo ( $\$ 338,600,910.54333$ ) higher than the revenue generated by the institution before the implementation of TSA (95\% CI [-119160115.99387, 796361937.08054]). This finding lends credence to the claim of Haruna, Alabade and Umar (2017) that TSA has the potential of increasing revenue generation in Nigeria.

In like manner, there was no considerable difference between the revenue generated by the Federal Teaching Hospital (FTH) Ido before the implementation of TSA and the revenue they generated after the implementation of TSA $\left(t_{2}=.513, p>0.05\right)$. Therefore, the second hypothesis of this study which states that "There is no significant difference between the revenue generated by the Federal Teaching Hospital Ido- Ekiti before the implementation of TSA and the revenue that the institution generated after the implementation of TSA" is hereby accepted. According to the result shown in the Table (95\%CI[-301109365.50781, 382667912.30781), on average, the revenue generated by FTHIdo after the adoption of TSA islower than the revenue generated by the institution before the implementation of TSA by forty million seven hundred and seventy-nine thousand and two hundred and seventy-three naira and 4 kobo ( $\$ 40,779,273.4)$.

Similarly, there was no statistically significant difference between the revenue generated by Federal Road Safety Commission (FRSC) Ado-Ekiti, before the implementation of TSA and the revenue generated by the parastatals after the implementation of TSA $\left(\mathrm{t}_{2}=2.293, \mathrm{p}>0.05\right)$. Therefore, the third hypothesis of this study which states that "There is no significant difference between the revenue generated by the Federal Road Safety Commission Ado- Ekiti before the implementation of TSA and the revenue that the parastatal generated after the implementation of TSA" is accepted. Furthermore, on average, the revenue generated by the parastatal after the adoption of TSA is five million, six hundred and thirty thousand naira ( $\$ 5630000.00)$ lower than the revenue generated before the adoption of TSA (95\% CI [-4933772.17980, 16193772.17980]).

In the same way, the revenue generated by the Federal Polytechnics (FEDPOLY) Ado after the implementation of TSA was not significantly different from the revenue generated by the parastatals before the adoption of TSA $\left(\mathrm{t}_{2}=\right.$ 4.024, $\mathrm{p}>.05$ ). Therefore, the fourth hypothesis of the study which states that "There is no significant difference between the revenue generated by the Federal Polytechnics Ado- Ekiti before the implementation of TSA and the revenue that the institution generated after the implementation of TSA" is accepted. However, on average the 
revenue generated by FEDEPOLY Ado after the implementation of TSA is ninety -five million, seventy-nine thousand and four hundred and seventy -two-naira sixty-seven kobo (\$95,079,472.66667) lower than the revenue generated by the institution before the implementation of TSA (95\% CI [-6587652.72676, 196746598.06009]).

Finally, the table reveals that the revenue generated by the selected federal parastatals in Ekiti state after the implementation of TSA was not substantially different from the revenues generated by the parastatals before the implementation of TSA $\left(t_{2}=-1.049, p>0.05\right)$. Therefore, the fifth objective of the study which states that "There is no significant difference between the revenue generated by the Federal parastatals in Ekiti state before the implementation of TSA and the revenue that the parastatals generated after the implementation of TSA" is accepted. However, on average, the revenue generated by the selected parastatals in Ekiti state was by one hundred and ninety-seven million, one hundred and twelve thousand and one hundred and sixty-four naira and forty-seven kobo ( 197112164.46667$)$ lower than the revenue generated by the parastatals before the implementation of TSA(95\% CI[1005344410.30934, 611120081.37600).

This study contradicts many existing studies which posit that TSA enhances federal government revenue, increases Transparency and accountability and reduces, corruption and financial leakages(Abodunrin \& Omole, 2017; Igbekoyi \& Agbaje, 2017; Ofor et al., 2017; Udo \& Esara, 2016). However, the outcome of this study lends assertion to the findings of Ofurum et al.( 2018)that the implementation of TSA has not enhanced revenue generation in Nigeria.

\section{Conclusion}

The study revealed that the implementation of TSA among federal government parastatals in Nigeria has not considerably improved the revenue generation among the parastatals. Specifically, the study established that TSA implementation has not brought about any significant improvement in the revenue generation of Federal University Oye Ekiti, Federal Medical Center Ido-Ekiti, Federal Polytechnics Ado-Ekiti and Federal Road Safety Commission Ado-Ekiti.

This study implies that the selected parastatals were either remitting all the revenues they were generating to the treasury even before the implementation of TSA or they were not as committed to their duties after the implementation of TSA as they were before the implementation of TSA. They might become less committed because they know the revenue generated would not come to their pockets like the former practices.

Moreover, this study reveals that on average, the revenue that the federal parastatals in Ekiti state generated after the implementation of TSA was lower than what they were generating before the adoption of TSA. The only institution that stands out is the Federal university Oye-Ekiti. The other three parastatals which include, Federal Teaching Hospital Ido -Ekiti, Federal Road Safety Commission Ado-Ekiti and Federal Polytechnics Ado-Ekiti generated lower revenue after the implementation of TSA than what they generated before the implementation of TSA. Therefore, on average, the revenue generated by the federal parastatals in Ekiti state after the implementation of TSA is lower than the revenue they generated before the implementation of the TSA. This outcome implies that the TSA is counterproductive.

Even though, the effect of TSA on revenue generation among federal government Parastatals in Ekiti state lacks significant statistical support, the study still suggests that the federal government should continue to enforce the policy. The basis of this suggestions lies on the increment in average revenue that the Federal University Oye Ekiti generated after the TSA which is higher than what it generated before TSA.

However, based on the decrease in average revenue that the other parastatals in Ekiti state recorded after the implementation of TSA which even swallowed the increment that the Federal University Oye-Ekiti recorded, the study recommends that the federal government should review the policy, investigate the challenges facing the implementation of the policy, and effectively monitor the implementation of the policy.

However, there was no enough data for the study. Firstly, the central bank of Nigeria (CBN)'s statements of account for federal parastatals in Nigeria is not accessible on the internet. This served as a great limitation to the study. The authors had to visit each parastatal to collect the secondary data from different sources. Moreover, none of the federal parastatals reveal their financial information with banks and government via treasury single account on the internet.

Notwithstanding the limitations, the study has been able to employ the available data to validly establish the effect of TSA implementation on federal government revenue in Nigeria. Future researchers are advised to work on larger sample size and find out the challenges facing the implementation of the TSA or reasons why TSA is counterproductive in Ekiti-state. They are also advised to investigate the effect of TSA on a particular sector such as health or education. 


\section{References}

Abodunrin, O. R., \& Omole, F. T. (2017). Treasury Single Account(TSA) policy and its effort in combating corruption in Nigeria. International Journal of Social Sciences and Humanities Review, 7(2), 90-96. https://doi.org/10.1016/S0009-2614(00)00764-8

Adetula, D., Adegbenjo, S., Owolabi, F., Achugamonu, U., \& Ojeka, S. (2017). Treasury Single Account policy and government revenue in Nigeria. Journal of Internet Banking and Commerce, 22(S8), 1-7.

Agbo, P. O., Suleiman, S. L. J., \& Okwoli, A. A. (2019). Effects of Treasury Single Account on cost of revenue generation in Nigeria. International Journal of Business Marketing and Management, 4(8), 2456-4559. Retrieved from www.ijbmm.com

Ahmed-Gamgum, W. A., \& Ahmed, R. W. (2018). The bases and challenges of Treasury Single Account ( TSA ) in Nigeria. International Journal of Social and Management Research, 4(1), 1-11.

Ajala, O. A., Adesanya, T. A., \& Oyewale, T. C. (2017). Treasury single account and Nigeria public financial management. Journal of Association of Professional Bankers in Education, 1(1), 110-195. Retrieved from http://apbe-cibn.org

Ajetunmobi, O. O., Adesina, K., Faboyede, S. O., \& Adejana, B. P. (2017). The impact of Treasury Single Account on the liquidity of banks in Nigeria. Journal of Accounting, Finance and Auditing Studies, 3(3), 132-143.

Ajibade, A. T., Oyedokun, G. E., \& Doumu, O. S. (2018). Treasury Single Account and public fund management: A study of selected federal government parastatals in Bayelsa State. International Journal of Scientific \& Engineering Research, 9(12), 890-902.

Amadi, L., \& Obutte, P. C. (2018). The treasury single account and the search for effective revenue management in Nigeria's oil and gas sector. Journal of Sustainable Development Law and Policy (The), 9(2), 101. https://doi.org/10.4314/jsdlp.v9i2.7

Badejo, B., Oluwaseyi, A., \& Taiwo, M. (2017). The nexus of Treasury Single Account policy in Nigeria: an exploratory discourse. Studii Financiare (Financial Studies), 21(3), 19-31.

Bashir, Y. M. (2016). Effects of Treasury Single Account on public finance management in Nigeria. Research Journal of Finance and Accounting, 7(6), 164-170.

Can, B. (2019). The likely impact of extended Turkish Treasury Single Account system on public finance in Turkey (Vol. 13).

Constitution, N. (2004). Constitution of the Federal Republic of Nigeria 1999. https://doi.org/10.1163/170873811X577302

Ejoh, N. O. (2020). Treasury Single Account ( TSA ) implications on government revenue control among federal government parastatals in Nigeria. IOSR Journal of Economics and Finance, 11(1), 18-25. https://doi.org/10.9790/5933-1101011825

Eme, I. O., Chukwurah, D. C., \& Emmanuel, N. I. (2015). An analysis of pros aand cons Treasury Single Account policy in Nigeria. Arabian Journal of Business and Management Review, 5(4), 20-39.

Eseoghene, O., Estemetan, R., \& Oghenevwogaga, O. (2018). Treasury Single Account ( TSA ) and transparency in public sector financial management in Nigeria. Journal of Accounting and Financial Management, 4(2504-8856), 82-92.

Esoimeme, E. E. (2019). A critical analysis of the anti-corruption policy of the federal executive council of Nigeria. Journal of Money Laundering Control, 22(2), 176-187. https://doi.org/10.1108/JMLC-06-2017-0021

Field, A. (2009). Discovering statistics using SPSS (3rd ed.). London: Sage Publication Ltd.

Ganyam, A. (2020). Effect of Treasury Single Account (TSA) on Financial Accountability, Corruption and Financial Discipline in the Nigerian Public Sector Effect of Treasury Single Account (TSA) on Financial Accountability, Corruption and Financial Discipline in the Ni. https://doi.org/10.13140/RG.2.2.25282.89280

Habeeb, A. S. (2020). Combating corruption in the nigerian civil service. Journal of Money Laundering Control, 23(1), 267-280. https://doi.org/10.1108/JMLC-05-2019-0039

Haruna, F. B., Alabade, A. A., \& Umar, U. O. (2017). Implementation of Single Treasury Account: Towards curbing corruption in Nigeria for good governance. IOSR Journal of Humanities and Social Science, 22(11), 11-17. https://doi.org/10.9790/0837-2211111117

Igbekoyi, O. E., \& Agbaje, W. H. (2017). An assessment of the implication of Treasury Single Account adoption on 
public sector accountability and transparency. European Journal of Accounting and Finance Research, 5(8), $33-49$.

Ikpesu, O. C. (2018). Business environment characteristics and new venture creation in Rivers State, Nigeria. Journal of Asia Entrepreneurship and Sustainability, 14(2), 64-94.

Ikya, E. A., Akaa, S. T., \& Ucherwuhe, S. I. (2017). Treasury Single Account: nature, origin, challenges and lesion for Nigerian experience. Imperial Journal of Interdisciplinary Research (IJIR), 3(5), 787-793.

Ikya, F. A. (2019). Banking the unbanked at the bottom of the economic pyramid in Nigeria: Challenges and opportunities for profitable growth. Journal of Internet Banking and Commerce, 24(2), 1-22.

Kanu, C. (2016). Impact of Treasury Single Account on the Liquidity. ABC Journal of Advanced Research, 5(1), 43-52. https://doi.org/10.18034/abcjar.v5i1.57

Lienert, I. (2009). Modernizing cash management. Technical Notes and Manuals, 2009(3), 1-22. https://doi.org/10.5089/9781462304127.005

Lodikero, O., Fagbayimu, M. O., \& Olateru-Olagbegi, A. (2018). Treasury Single Account: a tool for accountability and transparency in Ondo State, Nigeria. International Journal of Economics, Commerce and Management, VI(12), 56-71.

Mboto, H. W., Offiong, A. I., \& Ibor, B. I. (2017). Public perception of the Treasury Single Account in Nigeria. Journal of Economics and Development Studies, 5(2), 68-77. https://doi.org/10.15640/jeds.v5n1a7

Moses, O., Ehalaiye, D., Maimako, S., \& Fasua, K. (2018). Consequences of the treasury single account policy on the wealth of nigerian commercial banks' shareholders. Emerging Markets, Finance \& Trade, 54(9), 2078-2092.

Muraina, S. A. (2018). Effect of Treasury Single Account ( Tsa ) on deposit money banks' liquidity performance in Nigeria. International Journal of Family Business and Management, 2(2), 1-15.

Ndubuaku, V. C., Ohaegbu, O., \& Nina, N. M. (2017). Impact of Treasury Single Account on the performance of the banking sector in Nigeria. Journal of Economic and Finance, 8(4), 8-15. https://doi.org/10.9790/5933-0804010815

Nwankwo, S. N. P. (2017). Transition to treasury single account (TSA) scheme in Nigeria; issues, challenges and prospects. International Journal of Innovative Finance and Economics Research, 5(2), 21-32.

Ofor, N. T., Omaliko, L. E., \& Okoli, F. C. (2017). Effect of Treasury Single Accounts (TSA) on the Performance of Ministries, Departments and Agencies ( MDA ) in Nigeria. Trends Economics and Management, 29(2), 59-67. https://doi.org/10.13164/trends.2017.29.59

Ofurum, C. N., Oyibo, P. C., \& Ahuche, Q. E. (2018). Impact of Treasury Single Account on government revenue and economic growth in Nigeria: A pre - post design. International Journal of Academic Research in Business and Social Sciences, 8(5), 283-292. https://doi.org/10.6007/ijarbss/v8-i5/4101

Oguntodu, J. A., Alalade, Y., Adekunle, Y., \& Adegbie, F. (2016). Treasury Single Account a nd Nigeria's economy between 1999 and 2015: An assessment. Journal of Accounting and Financial Management, 2(6), 61-75.

Oti, P., Igbeng, E., \& Ndifon, O. E. (2016). Appraisal of policy impact of Treasury Single Account in Nigeria. Research Journal of Finance and Accounting, 7(20), 45-52.

Pattanayak, S., \& Fainboim Yaker, I. (2011). Treasury Single Account: an essential tool for government cash management. Technical Notes and Manuals, 11(4), 1. https://doi.org/10.5089/9781475504699.005

Udo, E. J., \& Esara, I. E. (2016). Adoption of Treasury Single Account (TSA) by state governments of Nigeria: benefits, challenges and prospects. Journal of Finance and Accounting, 4(3), 126-130. https://doi.org/10.11648/j.jfa.20160403.14

\section{Copyrights}

Copyright for this article is retained by the author(s), with first publication rights granted to the journal.

This is an open-access article distributed under the terms and conditions of the Creative Commons Attribution license (http://creativecommons.org/licenses/by/4.0/). 